Photostat Price \$_
Microfilm Price \$
Available from the
Office of Technical Services
Department of Commerce
Washington 25, D. C.
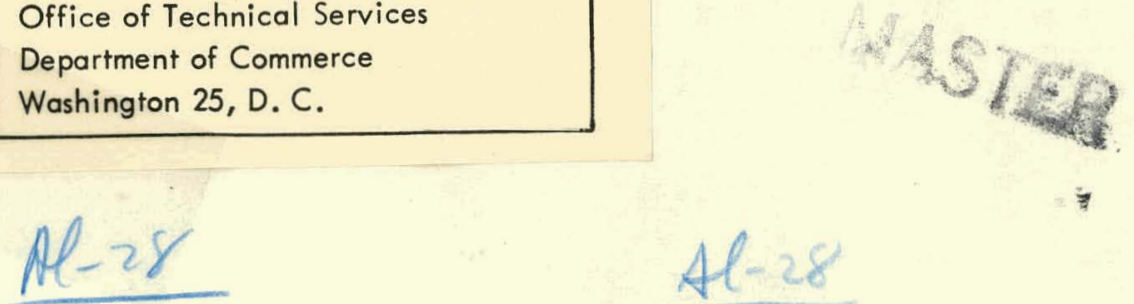

\title{
THE MAGNESIUM-28-ALUMINUM-28 SYSTEM: AN ALUMINUM-28 GENERATOR
}

\section{Allen J. Weiss and Manny Hillman \\ The Hot Laboratory \\ Brookhaven National Laboratory \\ Upton, New York}

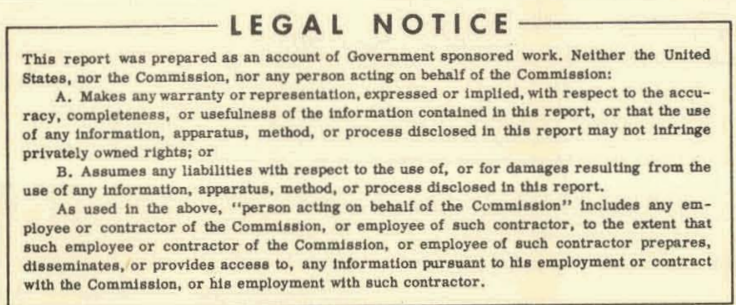

March 15, 1963

To be submitted to the International Journal of Applied Radiation and Isotopes 


\section{DISCLAIMER}

This report was prepared as an account of work sponsored by an agency of the United States Government. Neither the United States Government nor any agency Thereof, nor any of their employees, makes any warranty, express or implied, or assumes any legal liability or responsibility for the accuracy, completeness, or usefulness of any information, apparatus, product, or process disclosed, or represents that its use would not infringe privately owned rights. Reference herein to any specific commercial product, process, or service by trade name, trademark, manufacturer, or otherwise does not necessarily constitute or imply its endorsement, recommendation, or favoring by the United States Government or any agency thereof. The views and opinions of authors expressed herein do not necessarily state or reflect those of the United States Government or any agency thereof. 


\section{DISCLAIMER}

Portions of this document may be illegible in electronic image products. Images are produced from the best available original document. 
THE MAGNESIUM-28-ALUMINUM-28 SYSTEM: AN ALUMINUM-28 GENERATOR*

\author{
Allen J. Weiss and Manny Hillman \\ The Hot Laboratory \\ Brookhaven National Laboratory \\ Upton, New York
}

Of the known aluminum isotopes, one, $\mathrm{Al}^{26 \mathrm{~g}}$, has a very long half-life, but is difficult to prepare in reasonable quantities, two, $\mathrm{Al}^{28}$ and $\mathrm{Al}^{29}$, have very short half-lives, $2.30 \mathrm{~m}$ and $6.6 \mathrm{~m}$ respectively, almost too short to use in tracer experiments, and the rest have half-lives of the order of a few seconds or less. For experiments where integrated energy absorption is an important factor, e. $g$. physiological experiments, $A^{28}$ or $A^{29}$ would be more suitable than $A 1^{26}$.

$A 1^{28}$ and $A^{29}$ may be prepared directly by means of a number of nuclear reactions; for example, $A 127(n, \gamma) A 128$, $\mathrm{Al}^{27}(t, p) \mathrm{Al}^{29}, \mathrm{Si}^{28}(\mathrm{n}, \mathrm{p}) \mathrm{Al}^{28}, \mathrm{Si}^{29}(\mathrm{n}, \mathrm{p}) \mathrm{Al}^{29}$, etc. All of these methods, however, suffer at least one drawback. They all require an extremely fast method of purification of the newly formed isotope and subsequent fast incorporation in the medium under study. The difficulty alone in handling freshly irradiated materials and in separating the desired activity from side products need not be emphasized further. Far superior to direct preparation is a method of milking the desired isotope from a longer lived precursor. This can be done with $\mathrm{Al}^{28}$.

$\mathrm{Mg}^{28}$ decays with a $21 \mathrm{~h}$ half-life to $\mathrm{Al}^{28}$. It is readily available from the $\mathrm{Mg}^{26}(t, \mathrm{p}) \mathrm{Mg}^{28}$ reaction and can be obtained commercially $(1)$. The commercial material, prepared by irradiation of a $\mathrm{Li}^{6} \mathrm{Mg}^{26}$ alloy in the Brookhaven Graphite Research Reactor, and purified by a combination of hydroxide precipitation and ion exchange through Dowex-l and alumina, was still

*This work was performed under the auspices of the U. S. Atomic Energy Commission. 
found to contain a small amount of impurity, identified as $\mathrm{Cd}^{115}$ and $\mathrm{Cu}^{64}$. These were removed by sulfide precipitations in the presence of $\mathrm{Cd}$ and $\mathrm{Cu}$ carriers. The $\mathrm{Mg}^{28}$ solution was then placed on a Dowex 50W columin in the $\mathrm{Na}^{+}$form and washed with $200 \mathrm{ml}$ of $1 \mathrm{~N} \mathrm{NaOH}$. This removed additional unidentified impurities.

The column, Fig. 1, as prepared above, now serves as a generator for $\mathrm{Al}^{28}$ of exceptional purity. The $\mathrm{Al}^{28}$ is eluted in 10-30 seconds, giving a $30 \%$ yield, by means of a $1 \widehat{\mathrm{N} \mathrm{NaOH}}$ solution containing $0.5 \mathrm{mg} / \mathrm{ml}$ of carrier aluminum. The column may be eluted repetitively, after allowing a few minutes between elutions for $A 1^{28}$ to grow back in. Al28 has the shortest half-life of any nuclide for which a useful generator has been developed.

The advent of exceptionally pure $\mathrm{Mg}^{28}$ and $\mathrm{Al}^{28}$ made it possible to determine their half-lives apparently more accurately than heretofore. After $A 128$ had grown into equilibrium, the $\mathrm{Mg}^{28}$ was counted for about fourteen halflives in a well-type gamma scintillation counter and with an end window beta-proportional counter. The $\mathrm{Al}^{28}$ was counted for over three half-lives with both a 76 × $76 \mathrm{~mm}$ NaI(TI) gamma scintillation counter and with a plastic beta-scintillation counter, both coupled to a TMC-402 analyzer operated in the multiscaler mode. The data was analyzed by means of the least squares method. The impurities in the samples were found to be present in less than.01\% for the $\mathrm{Mg}^{28}$ and less than . $1 \%$ for the $\mathrm{Al}^{28}$. The results are tabulated in Table 1.

\section{TABLE 1}

\section{HALF-LIVES}

No. of

Nuclide Determinations $\mathrm{Mg}^{28}$ 20

A 128

16

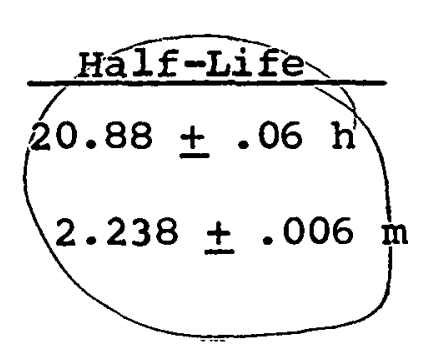

Other Values (References)

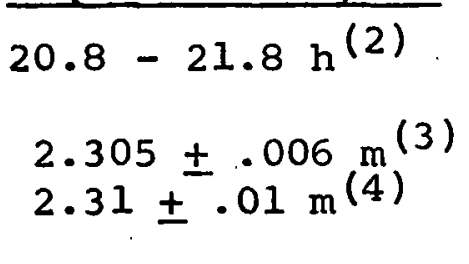




\section{REFERENCES}

(1) "Processed Isotopes Available from Brookhaven National Laboratory", 1960.

(2) Cf. D. Strominger, J. M. Hollander, and G. T. Seaborg, Rev. Mod. Phys., 30, 585 (1958).

(3) J. O. Elliot and F. C. Young, Nucl. Sci. and Eng., 5, 55 (1959).

(4) S. Malmskog and J. Koniju, Nucl. Phys., 38, 196 (1962). 


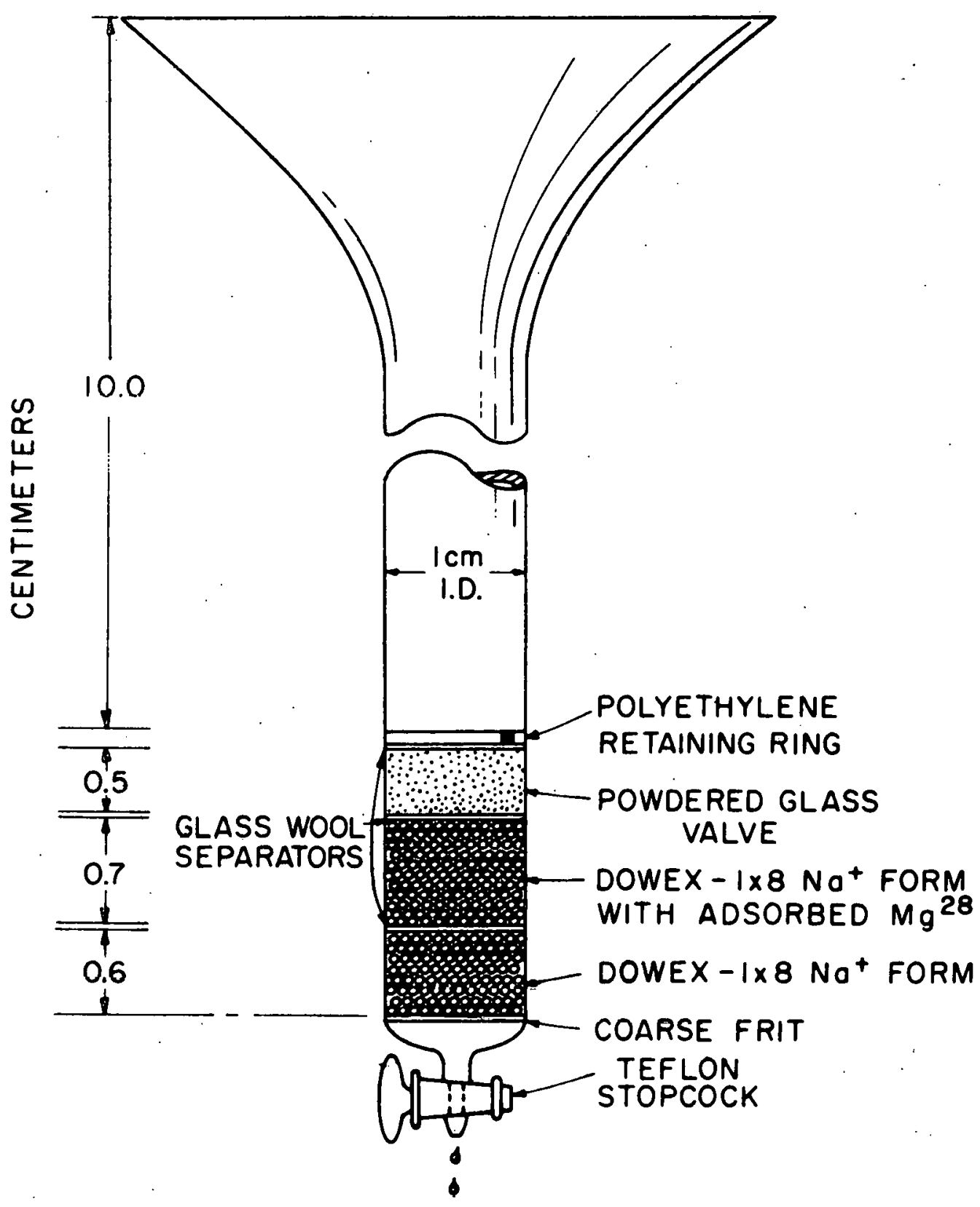

FIG.I ALUMINUM - 28 GENERATOR 